\title{
EMPOWERMENT OF FISHING COMMUNITY BUSINESS GROUPS IN KALIBARU VILLAGE, CILINCING, NORTH JAKARTA
}

\author{
Giyatmi Giyatmi ${ }^{1 *}$, Iman Basriman ${ }^{1,}$ Abdul Harif Siswanto ${ }^{2}$, Hari Eko Irianto ${ }^{1}$ \\ ${ }^{1}$ Study Program of Food Technology, Sahid University - Jakarta, ${ }^{2}$ Study Program of Communication Science, \\ Sahid University - Jakarta \\ *giyatmi@hotmail.com
}

\begin{abstract}
The purpose of this activity was to empower fishing communities in Kalibaru, Cilincing through introducing knowledge of food handling and processing technologies, especially green mussels-based products. The partner involved in this study was the Annisa Bakti Business Group having 15 members of single parents. The profession of family members was green mussels peeler. Peeling process performed was through boiling, peeling the shell, icing, and then selling. The handling of green mussels with peeling was mainly intended to solve the problem overproduction which was not absorbed by the market as life green mussels. The appearance of peeled green mussels were usually pale, and the peeler usually introduced synthetic dyes to make them more attractive. The types of dyes used are generally not allowed for food because they are harmful to health. Based on those facts, the community empowerment efforts were carried out through the following ways: (1) Building motivation to develop the business; (2) More hygienic handling of green mussels; (3) Training on oyster (mussels) sauce processing; (4) Development of processed mussels product business, through introducing simple business feasibility study, business management, and simple financial bookkeeping. The program is expected to have an impact on improving the welfare of partners, especially the Annisa Bakti. Business Groups.
\end{abstract}

Keywords: Annisa Bakti, community empowerment, green mussels, oyster sauce, synthetic dyes

\section{INTRODUCTION}

Empowerment of Kalibaru Urban Fishing Community Business Group, Cilincing North Jakarta is partnering with the Annisa Bakti Business Groups. The group is a fishing community founded in 2008 with as many as 15 members. All members are mothers with single family status. The Annisa Bakti Business Groupswas formed with the intention of accommodating the efforts of members of different professions and businesses, but most of them work as green mussel peelers. Kalibaru Village is a center of fisheries, especially green mussels, but from fisheries activities it has a lot of business impacts other than fisheries. The types of businesses trade members such as trading green mussels, dried fish, wet fish, uduk rice, vegetables, cakes and fish crackers. For the marketing area, the average business activity is still carried out around the Cilincing District. There are even some members who sell at home, except for members of dry fish traders, the marketing area reaches Bogor. The patners at the beginning of its establishment aimed at the realization of the quality of their life, the advanced, independent, prosperous fishing communities in the efficient and effective network of work for its members and groups.

The partner group cultivates saving activities, not only by getting used to saving regularly, but also getting used to frugality. Frugality in the sense of spending existing funds in accordance with the interests needed by developing an attitude of orienting each expenditure on productive activities. Cultivating savings and credit activities also means the readiness of funds that will be used for productive purposes, namely for working capital. The business will produce more value so that it can be used for the benefit of a day or family needs, and the excess is saved as a deposit.

In the Kalibaru Village area, it is known as the cultivation of green mussels. Green mussels is one type of shellfish that is favorited by peoples, has economic value, and is very good for consumption, 
which consists of $40 \%$ water, $21.9 \%$ protein, $14.5 \%$ fat, $18.5 \%$ carbohydrates, and $4.3 \%$ ash. Every day harvested green mussels are not less than 500 sacks, each sack contains $50 \mathrm{~kg}$, so the total production is approximately 25 tons per day. Generally, people sell green shells in the fresh form of life, still in shells with bucket size. One bucket of green mussels contains approximately $7 \mathrm{~kg}$ and is valued at Rp10,000 - Rp15,000. If after some time the mussels are not sold out in living conditions, the green mussel is stripped/peeled. Mussels stripping is intended to facilitate the storage process. If it is not sold out, then the mussels was boiled, stripped and given ice in storage. Freezing and storage help to even out seasonal catch rates, and provide a more uniform supply of high quality raw material to consumers and to secondary processors. The peeled green mussels are sold at a price of Rp. 10,000 per kilograms. The activity of handling and stripping green mussels in Kalibaru village is presented in Figure 1.
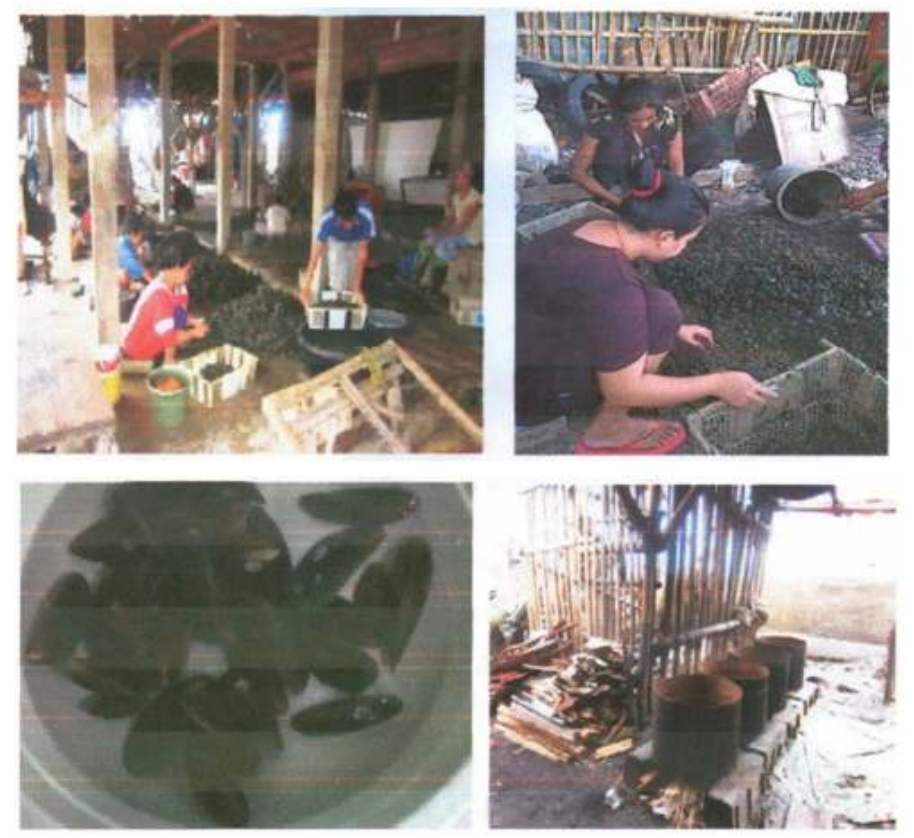

Figure 1. The activity of handling and stripping green mussels in Kalibaru village

Green mussels produced by Kalibaru Village, even in general in Indonesia, have not been much processed. Handling of green mussels with stripping is mainly intended to overcome the excess production that is not sold out in life form. Before being peeled, the shells are treated with boiling in order to open the shells. Peeled mussels are generally pale in colour, so mussels peeler usually adds a dye liquid to make it look more attractive. The type of dye used by partners usually uses a chemical that is not permitted for food, such as textile dye. In processed form, boiled mussels meat is often given a dye that is not for food (non-food grade) such as a mixture of Rhodamine B and methanyl yellow so that its appearance is more attractive (Rahayu and Firdaus, 2008). This type of dye is very dangerous, because it contains Rhodamine B which is harmful to health. Rhodamine B is a synthetic chemical dye in the form of green crystalline powder or purplish red powder which is easily soluble in alcohol, slightly soluble in $\mathrm{HCl}$ and $\mathrm{NaOH}$ which is commonly used in the fleece industry, silk paper and textiles. In addition, Rhodamine B also contains very high content of heavy metals (Anonymous, 2006 in Dwiyitno, 2009). From the counseling provided by the relevant agency, the Kalibaru Urban community actually knew this, but the traders who were supplied generally still requested that the mussels be given a color so as not to look pale. They generally sell green mussels at dawn, where peel shells that are not given color when highlighted by the lamp will look unattractive. Ironically, partners said that they themselves did not want to consume peeled shells that had been plated with the harmful dye. With this background, the business of processing green mussels-based products should be a priority of concern, so business development is based on these commodities. Handling of mussels which currently still uses processes that endanger the health of consumers, then in this activity an effort will 
be made to handle more hygienic shellfish products. However, this effort needs more intensive socialization or education to all parties, both to producers and consumers. Currently marketing of shellfish shells is done with a bulk system. For this reason, in this activity alternative handling and marketing of more hygienic shelled green shells is done by means of shelled shells packed and cooled during marketing.

Each label will be labeled and stated that the peel shells do not use a chemical that is hazardous to health and handled hygienically. This process is a direct socialization to consumers to jointly have awareness of food security. The packaged mussels is then marketed using a cold chain which is a prerequisite for handling fishery products. Growing awareness about the importance of fish quality in fulfilment consumption needs, began to increase the use of ice as a cooling medium large. On the other hand, the ineffective use of ice and its increasing availability limited encouragement of innovations to optimize ice use. One effective and economical way is to use insulated cool boxes ice-cooled to store products (Saputra, 2017).To reduce marketing costs, as well as to maintain hygiene, the cooling process used jelly ice pack. The use of this cooling material will last up to more than 12 hours, then this material can be used again by freezing it first.

Green mussels are commodities that are very vulnerable to damage so that there will be many losses if the mussels commodity is managed without the application of food technology. From the consumer side, marketing of green mussels in fresh form limits the market segment because the marketing area is limited. In this case, the processing of green mussels into processed forms will extend shelf life, processed shellfish products are more diverse, including processing into oyster sauce. The use of oyster wear oyster sauce in the community is well known not only among the Chinese community. This is because oyster sauce can be used as a substitute for flavouring, which generally comes from Monosodium Glutamate. Thus, the processing of oyster sauce will expand the market segment of mussels. In addition, the marketing of mussels in its intact form does not provide sufficient benefits or more value than if the mussels is marketed in its processed form.

The process of processing oyster sauce can be done with food processing technology and the use of simple equipment and can be applied on a small industrial scale. Partners have great potential to develop business forms of mussels processed products. Aspects of the availability of raw materials independently and the availability of resources can be developed into producers of processed mussels products that can produce continuously. But on the other hand, the potential that is owned is not supported by the knowledge of food processing technology, especially processing technology for mussels commodities, so that the existing resources cannot be fully empowered. For this reason, it is necessary to carry out debriefing about the knowledge of food processing technology to existing resources so that empowerment can be carried out fully. The provision of knowledge can be carried out in the training program for the package of mussels processing technology and adequate business management.

\section{METHOD}

\section{Approach Method}

Based on the problems that have been described previously, efforts to empowerment can be done by the following methods:

a. The process of building motivation

This process is intended so that the patners to be empowered have the same desire to advance the business of utilizing the commodities produced in the region. The existence of active participation will have an impact on improving their welfare.

b. Institutional capacity building

Institutional capacity building process for social partnerships that are rooted, representative and accountable fishing communities. The benefit of this activity is that the fishing community has an institutional model of social partnership for poverty alleviation that is appropriate to their own community environment. Based on the results of data analysis and the results of discussions conducted with relevant partners, the following programs are proposed:

1) Training in handling more hygienic peeled mussels

2) Training of shellfish processing technology packages into fermented oyster sauce processing 
products

3) Development of business of shellfish processed products, in the form of making simple business feasibility, business management, and financial report bookkeeping processes.

\section{Activity Plan}

To implement this empowerment method, the stages of empowerment activities are carried out with the following steps:

- The first stage, collecting data, facts and information related to the problem of the object of community development.

- The second stage, compiling a joint plan through a focused discussion approach. In this process all stakeholders are involved. The purpose of this discussion is to get support and agree on a solution to the problem together.

- The third stage, compile a work plan. The results of focused discussions are included in strategic plan matrix tables. The matrix will describe the objectives of the activity, location, scope, role of the parties involved, plans costs needed, indicators of success and the process of sustainability post mentoring.

- The fourth stage, a technical implementation plan that contains a time table detailed in a large table. It is expected that all interested parties know the plan to be carried out. With this way all resources are involved in the management process which includes: planning, organizing, reporting and supervision.

- The fifth stage, the implementation of planned and planned activities agreed with partners.

- The sixth stage, monitoring evaluation and preparing reports. At the stage this also carried out dissemination of the results of the implementation, so that it could be done thorough evaluation, discussing sustainability, and development efforts. Dissemination is also intended to provide a process learning for other activities. Overall activities subsequently published in the form of national-level scientific articles, so that indirectly it will also promote the business carried out by partners.

\section{Output Targets}

The output targets to be achieved in this activity plan are:

a. Members of KUB Bakti Annisa get appropriate technology training in the form of technology packages for handling and processing business mussels into commodities that are hygienically handled and become processed oyster sauce products.

b. Members of KUB Bakti Annisa received training on community empowerment models in the form of developing handling businesses or processed mussels products, including making a business feasibility study.

\section{RESULT AND DISCUSSION}

\section{Training in entrepreneurial motivation}

Motivation to raise the economic and social conditions of partner members through planned activities. The motivation was carried out by Drs. Sastra Wijaya was accompanied by the implementing team. Drs Sastra Wijaya is the Socio-Economic Researcher of the Ministry of Maritime Affairs and Fisheries, where the person concerned is the person who has initiated the formation of KUB Bakti Annisa, thus psychologically the managers and members of KUB were refreshed with the aim of establishing KUB (Figure 2). 


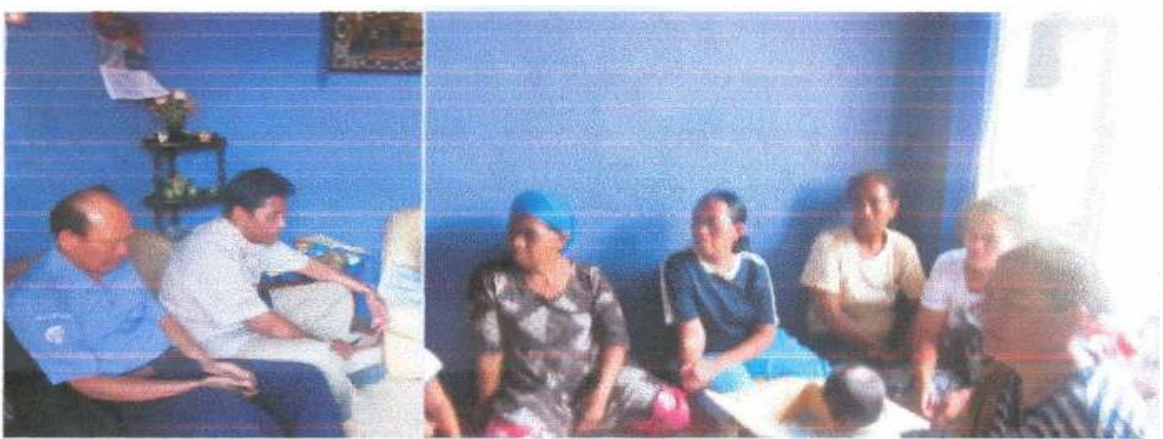

Figure 2. Motivation activity

Training in handling hygienic peeled mussels

The training on handling hygienic peeled mussels was carried out by the Team. In addition to being attended by members of the patners, this training was also attended by traveling mussels traders who sold seasoned boiled mussels. The involvement of these traders was due to the previous coordination meeting that peeled mussels produced by the Kalibaru community, Cilincing were generally sold by way of auctioned in Muara Baru. By involving these traveling traders, the products that will be produced by KUB Bakti Annisa as a business start will be entrusted as a product of the merchants of boiled shellfish traders. In addition to training in handling hygienic boiled mussels, at the same time also conducted counseling on food safety to partners, especially food safety of fishery products.

The production process of making peeled green mussel meat includes: a) Sorting and Washing; b) Boiling; c) Release of meat mussels; d) Washing and Sorting; e) Immersion in brine; and f) Packaging (Figure 3).

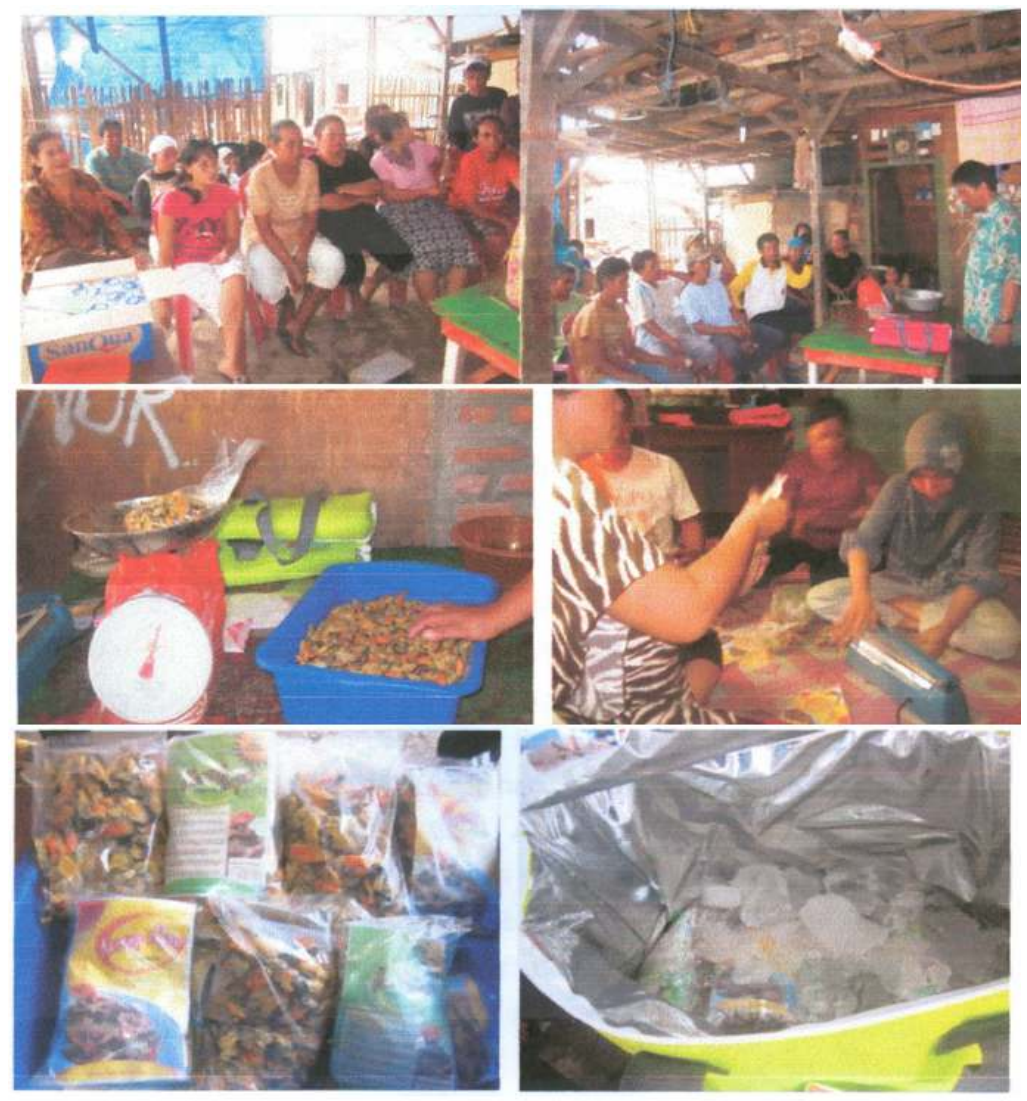

Figure 3. The production process of peeled green mussel meat 
a. Sorting and Washing

Green mussels are sorted according to their size and colour, which are green in color and measuring $5-6 \mathrm{~cm}$ in diameter. Sorting is done to find out the good green mussels. Good characteristics of green mussels are not slimy, skin and shells are still clenched and odourless. After sorting, washing is done by brushing the shells up from sludge and dirt, then rinsed with running water until clean.

b. Boiling

Mussels that still have shells are in great demand due to freshness indicator. Boiling the shells is done by boiling the water for as long as \pm 10 minutes. When the shell is open which means the shells are ripe. Shells that do not open their shells are discarded because they are not suitable for consumption.

c. Release of Mussels Meat

The green mussels meat are taken by using a knife, while the shell is removed. Characteristics of mussels meat that are suitable for consumption are the natural orange color of a little pale flesh, the typical smell of fishy, the taste is fresh sweet, and the textures are elastic, compact and solid as stated in SNI 01-3460-1994 (BSN, 1994).

d. Sorting and Washing

After getting the mussels meat, the sorting was done to get the uniform size and color of green mussel meat. Then it is washed with clean running water to remove the remaining dirt and at the same time the disposal of foreign objects attached to the meat of the green mussel.

e. Immersion

Soaking is done by putting green mussel meat into a brine solution with a concentration of $10 \%$ salt. Soaking is done for 5 minutes which aims to reduce the amount of bacteria that is still left during washing.

f. Packaging

The clean green mussel meat is then added as much as 250 grams into a LPDE type plastic bag. The packaging must be in a sterile condition and put in quickly which aims to reduce the entry of bacteria into the packaging from the air. Packaging is done to preserve green mussel meat during storage. With a variety of considerations, hygienic peel mussels are packaged in 250 grams and 500 grams are marketed by entrusting to mobile vendors, such as seasoned boiled mussel traders and vegetable sellers. For the purposes of these traveling traders, their carts are equipped with freezer bags.

\section{Peeled Green Mussels Marketing}

The mussels that have been peeled, are packaged in plastic with a size of 250 grams and 500 grams, then sealed. Product information that the peel mussels do not contain dyes and preservatives are printed on paper and put into small plastic bag (Figure 4). The information is then put into a second plastic that packs peel mussels, and is sealed so that it is neat and attractive. In the article also informed the nutritional value of green mussels. In this way it is expected that the public will be interested in buying by knowing the nutritional content of mussels and the product is also safe for consumption.

Packed green peel mussels are then put into freezer bags and given ice crushed or jelly ice to maintain the freshness and durability of mussels during marketing. The freezer bag is placed on a cart, so that it does not interfere with the movements and activities of the merchants. In addition, on the front and side of the cart, a sticker with information written on it said that the merchant, besides selling seasoned boiled mussels which are usually for the snack of the buyer, also brought / sold peel mussels which can usually be cooked for household side dishes (Figure 5). 

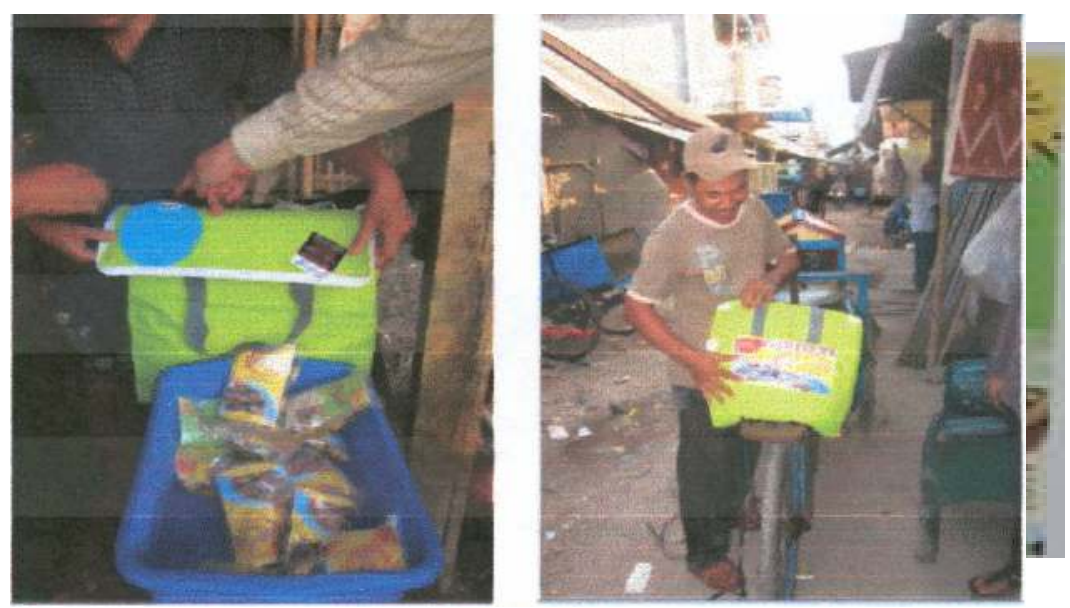

4. The label of green mussels packaged

Figure

Figure 5. Product placement on the back of the bicycle cart

Generally, traders sell their wares from 2:00 p.m. to early morning the next day. If this business develops well, it is expected that in addition to developing in KUB Bakti Annisa, the community or other traders can imitate this method. Thus the purpose of activities to educate people to consume safe food can be realized. Likewise the producers of peeled mussels no longer need to use ingredients that are harmful to body health.

\section{Training Application of Oyster Sauce Processing Technology}

Training in making oyster sauce made from shellfish starts with peeling shells that are still raw. For the activity of making oyster sauce, the raw material of shellfish must be fresh shellfish meat, not stew. After fresh shellfish meat is taken from the shell, then the fermentation process is carried out. In the fermentation process, other supporting ingredients are added, namely pineapple and salt chopped fruit. All ingredients are stirred and put into a jar. The fermentation process lasts 3-4 weeks at room temperature. After the fermentation process is complete, mix the shellfish, salt and pineapple crushed using a blender, then add water and spices and cook. The product is then put into a $200 \mathrm{ml}$ bottle, pasteurized and labelled (Figure 6).

The stages of the process of making green mussel sauce include the stages of cleaning and washing, soaking, weighing, mixing ingredients, fermentation, crushing, cooking, and filtering can be 
seen in the following flow:

a. Cleaning and Washing. Green mussels are cleaned with running water which aims to remove dirt that is attached to the shell. After that, remove the beards, then wash again clean.

b. Immersion. Soaking green mussels is done by using ice water for 1 hour 30 minutes. This soaking aims to open the green mussels without boiling. Soaking live shells in ice water is continued with stripping.

c. Weighing. Green mussels and other ingredients are weighed according to the desired amount.

d. Mixing salt and pineapple crushing. The green mussels that have been weighed are then added with salt and pineapple crush. Salt added as much as $25 \%$. Salt functions as a preservative. The addition of pineapple destruction is done to accelerate the process of protein hydrolysis and can soften the meat. The added pineapple destruction is as much as $10 \%$.

e. Fermentation. After mixing the salt and pineapple, the green mussels are fermented for 21-28 days at room temperature.

f. Destruction. Destruction is done to obtain smooth green mussels using a blender at a certain speed and time.

g. Cooking. At the time of cooking the fermented product is added with a ratio of 1:2 which aims to facilitate the stirring process and prevent physical damage. The cooking aims to homogenize a mixture of green mussels, salt and pineapple crushes. Cooking is usually carried out at a temperature of $70-80^{\circ} \mathrm{C}$ for 15 minutes. During the cooking process, green clam sauce is added with spices including brown sugar, garlic, coriander, ginger and corn starch.

h. Filtering. The green mussel sauce that has been formed is then filtered with a 40 mesh filter.

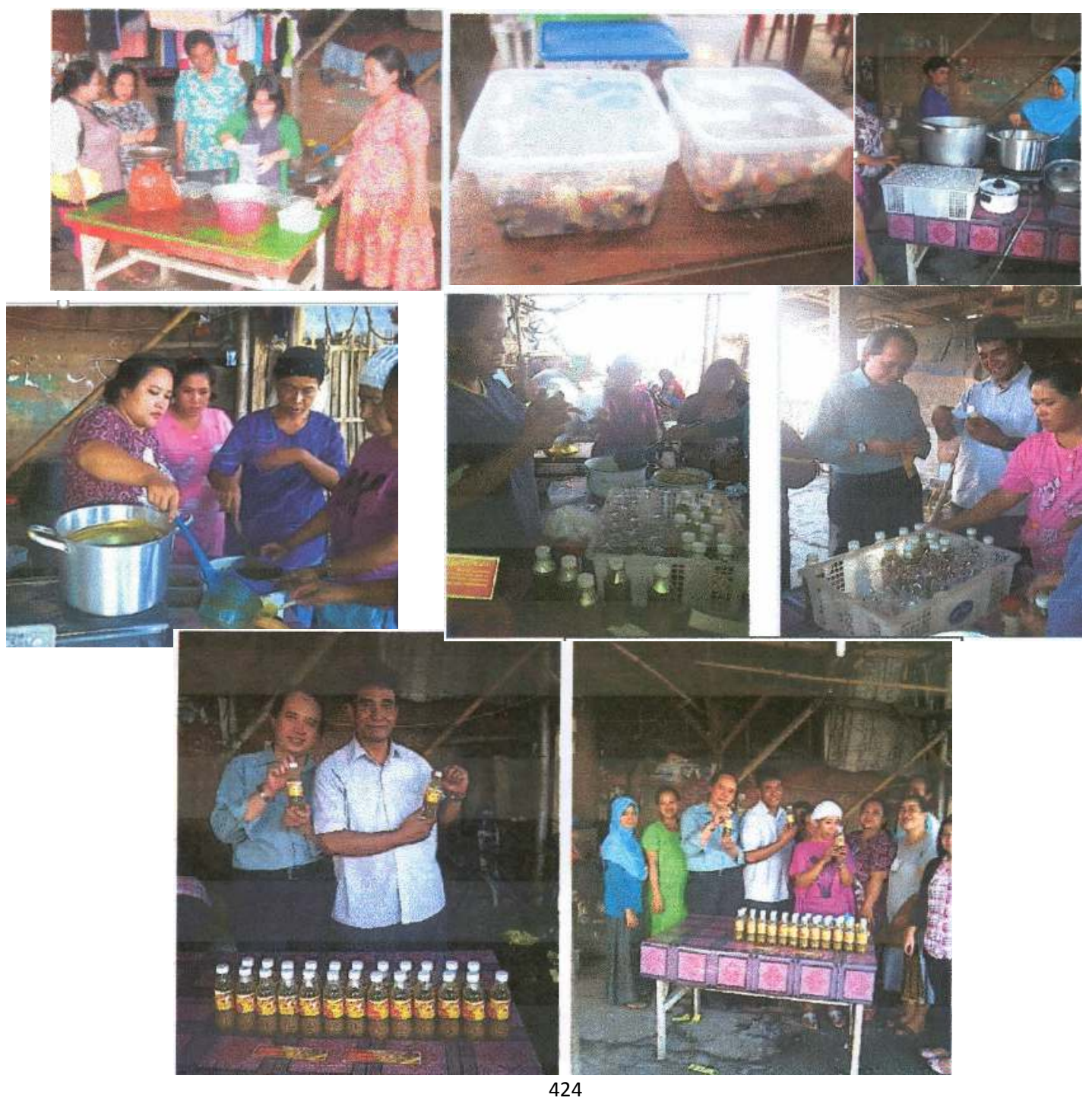


Figure 6. Training Application of Oyster Sauce Processing Technology

The trial of the marketing of oyster sauce made from green shellfish as a result of the development or diversification was done by being entrusted to traders who sell shelled shellfish, vegetable sellers and grocery stalls.

\section{Business and Management Development}

During the empowerment process training is carried out for business management, such as accounting and marketing innovation processes. Coaching is also carried out to calculate simple business feasibility. It is expected that if a partner later wants to develop his business. can independently calculate business feasibility from various factors, both technical, financial and marketing.

Technical factors that need to be considered to analyze the business feasibility of green mussel derivative products include the availability of raw materials both from quantity, quality; availability of technology, equipment machinery, availability of human resources, supporting infrastructure; and aspects of waste management. In the business feasibility analysis for handling and processing green mussel derivative products in the form of hygienic peeled mussels and oyster sauce, these technical aspects are not a problem. This is because abundant raw materials are available, technology and equipment used are available and simple, labor is sufficient and as part-time jobs outside of daily routine activities, supporting infrastructure such as water sources, electricity sources, transportation and communication equipment are available adequately, and do not cause waste that endangers the environment.

\section{CONCLUSION}

Based on these activities, the purpose of this motivation is to educate people to produce and consume safe food can be realized. The motivation was carried out so it can help to raise the economic and social conditions of partner members through planned activities, also psychologically the managers and members of KUB Annisa Bhakti were refreshed with the aim of establishing KUB. The training on handling hygienic peeled mussels was being attended by members of the patners, also attended by traveling mussels traders who sold seasoned boiled mussels. This training teaches the the producers of peeled mussels no longer need to use ingredients that are harmful to body health and make another product such as oyster sauce to utilize the unsold of raw green mussels. With business and management development rovided, its expected that people who want to develop other derivates of mussels products can independently calculate a simple business.

\section{ACKNOWLEDGEMENT}

Acknowledgments were conveyed to the Directorate of Research and Community Development - Directorate General of Higher Education (DRPM - DIKTI) Ministry of Research and Higher Education which has financed this activity.

\section{REFERENCES}

Dwiyitno, D., Priyanto, N., Wulanjari, W. A., \&Atmawidjaja, S. (2009). Toksisitas subkronik kerang hijau (Pernaviridis) yang diberi pewarna sintetik terhadap hati mencit. Jurnal Pasca panen dan Bioteknologi Kelautan dan Perikanan, 4(2), 113-120. 
Kolbe, E., Kramer, D. E., \& Junker, J. (2006).Planning seafood cold storage. Fairbanks, AK: Alaska Sea Grant College Program, University of Alaska Fairbanks.

Rahayu, N. S., \& Firdaus, F. (2008). Profil Food Safety Knowledge and Practice Unit-Unit Rumah Tangga di KabupatenSleman. Jurnal Logika, 5(1).

Saputra, A. C., \& Baheramsyah. (2017). Studi eksperimen penggunaan ice gel sebagai media pendingin cool box kapal ikan tradisional. Prosiding Seminar Nasional Kelautan dan Perikanan III 2017 Universitas Trunojoyo Madura, 7 September 2017 